\title{
AN EMPIRICAL STUDY ON GENESIS, GROWTH AND STATUS OF AKSHAYA TELECENTRES
}

\author{
Sreejith $\mathbf{S}$ \\ School of Legal Studies, Cochin University of Science and Technology, India
}

\begin{abstract}
Akshaya is a Kerala Government initiated project for the purpose of enhancing the speed of e-literacy, in public especially in rural areas through a Public Private Partnership (PPP) entrepreneurship programme. Akshaya Telecentres addresses as the information communication access point to the public, one for every 1000 families living in two or three municipal or panchayat wards. The project was launched on November 2002 with the model of social entrepreneurship as an initiative to provide equitable access to Information and Communication Technology (ICT) throughout the state. This project has involved in setting up of Telecentres across Kerala. A Telecentre is a community centre that offers shared access to Information and Communication Technologies (ICT) for the purpose of community level development and poverty reduction. Telecentres have to function like any other enterprise with an objective to achieve Sustainability. This study was conducted in order to assess the present status of Akshaya Telecentres in Kerala. The relevant dimensions and subsequent content areas of entrepreneurial competencies vary by the nature of entrepreneurial task and context within which they are performed. The study shows what is known about Telecentre entrepreneurs in terms of demographics, psychological, work behavior and competencies. In addition to the competencies of the entrepreneur, Telecentres require effective and dynamic organisational arrangements. Such arrangements are required for mobilising, organizing, utilizing, developing and protecting resources.
\end{abstract}

Keywords

Telecentre, Akshaya, Entrepreneurs, ICT, Community Development

\section{INTRODUCTION}

Technologies (ICT) for the purpose of community level development and poverty reduction [32]. The link between development and the increased use of ICTs in development is based on two assumptions (i) a new kind of economy is emerging: an information economy, (ii) main constraint to development is knowledge or information gap. The Government of India has visualized the National e-Governance Plan (NeGP) to set up 2,50,000 Telecentres in India with the objective to make all government services accessible to the citizen local through Common Service Centres (CSCs). NeGP also aims at ensuring efficiency, transparency and reliability of such services at affordable costs to reliable basic needs of the citizen [3].

'Akshaya' a Kerala Government initiated project for the purpose of enhancing the speed of e-literacy, in public especially in rural areas through a Public Private Partnership (PPP) entrepreneurship programme. The word Akshaya stems from the Sanskrit word Kshaya means loss. Akshaya means everlasting, complete, never ending eternal References can be given for this meaning from the Mahabharat's famous 'Akshaya-patra' story. It was a vessal that would endow unending riches, especially food to its bearer. Akshaya Telecentres addresses as the information communication access point to the public, one for every 1000 families living in two or three municipal or panchayat wards. The project was launched on November 2002 with the model of social entrepreneurship as an initiative to provide equitable access to Information and Communication Technology (ICT) throughout the state. This project has involved setting up of Multipurpose Community Technology Centre across Kerala.

\subsection{BACKGROUND OF THE STUDY}

ICT is defined as a set of activities that facilitate the processing, transmission, and display of information by electronic means. Generally, ICT has made a great impact on economic growth and social development by: (1) enhancing the productivity and efficiency of existing sectors and industries; (2) creating new business and development opportunities (3) facilitating an open economy and promoting a competitive market environment through enhanced information accessibility; and (4) improving quality of life and human well-being through accessibility to various new e-services. However, in order to fully exploit those benefits from applying ICT to the existing economy, it is important to strengthen a set of complementary factors that assist the necessary socio-economic transformation of the economy. These include the mind-sets of people, ways of communicating, the structure of the economy, and the level of literacy [15].

Between 1992 and 2002, ICT penetration increased significantly in developing countries. There are many challenges to overcome in setting up of Community e-Centres (CeCs), including the high costs involved in the establishment of the centres. When sustainability of a $\mathrm{CeC}$ is discussed, it is often interpreted as meaning self-financing and is equated with success. However, sustainability has many other dimensions, such as social and cultural, political, technological, and financial. ICTs are enablers of sustainable development rather than ends in themselves, the first task in developing a multi-stakeholder ICT partnership is to understand what the development goal is that the partnership is intended to deliver. In the first instance, this is most likely to be chosen by the organization that is self-elected to convene the initial discussions, and is usually developed as a simple and consistent "theme". Over time this theme often transforms, by consensus, into the overall vision or leading objectives of the partnership [28].

$\mathrm{CeCs}$ support local government functions in forming communities of interest to address key issues across government and the private sector. CeCs can develop capacity of local community and government by providing users with information and knowledge, as well as enhancing skills in business management, economics, accounting, trading through vocational training and education support [18].

CeCs can create long-term, self-sustaining solutions which reflect local needs, but they require local entrepreneurship, which 
in turn, can fuel the creation of additional local business community enterprises. The CeCs need to be made available in larger numbers and information exchange must be available at lower costs if recent ICT advances are to have a significant impact on development [26].

The role of government in increasing access to information is crucial. E-government can play an important role. In egovernment interactions, the government creates the egovernment platform in partnership with central government ministries, legislative and judicial authorities and local government and administration [14].

In Telecentre programme, harnessing the power of partnerships is very important. It is only through partnerships that the gap between "scientific know-how" and "field-level do-how" can be bridged. Therefore, for $\mathrm{CeC}$ programmes to succeed they need to ensure they bring in partners from sectors relevant to their users, for example in agriculture, education, weather, health and business [26].

\subsection{STATEMENT OF THE PROBLEM}

Telecentres have to function like any other enterprise with an objective to achieve Sustainability, as it cannot depend on external financial support [22]. Raul and Colle have recommended improved Telecentre governance structure and streamlining their operations and management from an enterprise point of view [25]. Optimal functioning of Telecentres in rural and remote communities requires basic telecommunication infrastructure. National level policy that support deregulated and regulatory framework for al Telecentre programme would be able to build Telecentre infrastructure for the nation [12].

In addition to the competencies of the entrepreneur, Telecentres requires effective and dynamic organizational arrangements. Such arrangements are required for mobilizing, organizing, utilizing, developing and protecting resources. Entrepreneurial competencies of the Akshaya entrepreneurs and organizational arrangements of Akshaya Telecentres are required to be measured and evaluated. In practice, Telecentres are financially viable if they cover their operating cost. Financially, achieving break even and being able to pay for all the expenses incurred in the running of Telecentre and maintaining the infrastructure available at the Telecentre are considered important in terms of Sustainability. It primarily referred to the capacity of the Telecentres to generate enough revenue to run successfully [27]. An investigation about the present status of Akshaya Project can illustrate the capability to ensure the sustainability of the Telecentre and to help to mobilize resources for that promote access and use of ICT.

\subsection{OBJECTIVES OF THE STUDY}

The present research study was taken up with the following objectives.

- To examine the present status of Akshaya Telecentres in Kerala.

- To identify profiles of Telecentre entrepreneurs in Kerala.

\subsection{SCOPE OF THE STUDY}

The study is intended to throw light on the present status of Akshaya Telecentres. The study is vital to various Stakeholders of Telecentre and has many policy implications. There are a lot of services that can be linked with the project from Government as well as private players. So these players can make use of the scope of converting Akshaya Telecentres as an alternative channel for their service delivery. The study will equip the policy makers with all predominant socio-economic factors that influence the Telecentres and based on the findings the Government can formulate strategies. This study will help the industry to plan its investment. Above all, the result of this study will motivate each and every stakeholder to have an internal retrospection to review their contribution to Akshaya Telecentres.

\section{REVIEW OF LITERATURE}

The first community technical centre was opened in Harlem, USA, in 1983, with the primary aim of bridging the growing digital divide between the upper and lower levels of society; $\mathrm{CeCs}$ offered free access to technologies and placed great emphasis on training [17]. However, the idea of creating places where the members of a community could access Information and Communication Technologies can be traced back to 1985 in the villages of Vemdalen and Harjedalen [17].

The authors distinguish between two Telecentre models in Europe, the Scandinavian model with a specific social aim: the Telecentres must provide information and communication technologies for the population of the small settlements in the long run, supporting by this the development of the rural and village societies and the more profit-oriented Anglo-Saxon model, which initiatives that provide long-term access to the ICT devices primarily aiming at profit production. The name Telecottage commonly indicated the Scandinavian model, highlighting the community and development aspect of the centre, while Telecentre denoted the Anglo-Saxon model, underscoring the commercial goal of the centre. However, in the following years this terminological distinction gradually disappeared and Telecentre became the most commonly used name for all the different types of centres described above except for Hungary, where Telecottage became the household name for Telecentres [17].

Telecentres of both types were soon imitated by the governments of Canada, Australia, Great Britain and Hungary. The adoption of the Scandinavian model aimed to give disadvantaged communities new educational and economic opportunities through ICT. For example, the Western Australia Telecentre Network aims to give rural communities access to higher education and the Telework, Telecottage and Telecentre Association aims to meet the employment needs of rural and economically. Based on criteria such as location, services offered and type of hosting organization. The following typologies are described: Basic Telecentre: usually located in rural areas where there is limited access to basic services in general and where, in addition to internet access, training of potential users is a popular service. Townsend, [29] proposed a different classification of Telecentres based on a mix of criteria: size, technologies and services offered and describe the following models of Telecentres. A more exhaustive definition of the Multi-Purpose Community Centre typology is given in [6] as Telecentres are intended for all 
members of a rural community or a deprived urban area with the objective to provide universal access to ICT. IT will provide a wide range of ICT-based services.

Fillip and Foote, [8] developed a timeline for Telecentres, defining three periods and optimistically looking towards the future:

Roman and Colle [25] defined Telecentres as a public place where people can get a variety of communication services as a general umbrella term for the experience of shared access, and grouped them into the following three categories according to two main criteria: their public or private orientation and the services offered.

Owen and Darkwa [21] whose research focuses on Ghana, divided Telecentres into two broad categories based on their public or private orientation.

Etta and Wamahiu, [7] said that a Telecentre is an integrated information and communication facility that houses a combination of both new and not so new ICT.

Oestmann and Dymond [20] indicate the following goals of Telecentres in transition and developing countries: expand access to ICT-based services, extend the reach of public services such as education, health and social services; provide information of general interest to the local community including government information and information of interest to specific groups such as farmers, local businesses and non-governmental organizations (NGOs); and provide access to infrastructure, technology support and advice for the growth of businesses.

Colle and Roman, [4] highlighted the main international donors in the incubation phase of the Telecentre movement: UNESCO-United Nations Educational, Scientific and Cultural Organization, ITU-International Communication Union, USAIDUnited States Agency for International Development, IDRCInternational Development Research Centre and Food and Agriculture Organization which are all still important today. Each of these players defined its own strategy and drew up its own program. ITU has set up and supported Telecentre projects around the world and has used the Multipurpose Community Telecentres (MCTs) model in 24 countries [6].

UNESCO's mission as regards Telecentres is to provide and expand communication and information facilities in local communities in order to offer basic tools for the introduction and management of community-centered development and change. UNESCO (with the support, inter alia, of SDC-Swiss Agency for Development and Cooperation) created the Community Multimedia Centres (CMCs) model which combine community radio managed by locals broadcasting in local languages with community Telecentre facilities. The program got off the ground in 2001 with 40 CMCs set up in over 15 developing countries in Africa, Asia, and the Caribbean during the pilot phase. The scaleup phase of the CMCs then began in 2004 with three countries in Africa (Mali, Mozambique and Senegal) selected for the development of a national network of 50 CMCs [11].

Harris, [10] professing that the Telecentre movement has now moved on from its pilot phase to the so-called Telecentre 2.0 phase. Harris points out that the Telecentre 2.0 phase exists within the Telecentre ecosystem; i.e. a network of Telecentres, information providers and support institutions that serves to strengthen the movement towards widespread enjoyment of the benefits that Telecentres bring. His idea is that countries lagging behind in Telecentre deployment can now skip the pilot phase thanks to the experience of those countries which have already gone through it and are now implementing Telecentre 2.0.

Telecentres fall within the framework of global initiatives grounded in the belief that the creation and sharing of information and knowledge represents a key to economic and social development International development activities should therefore address the digital divide since access to telecommunication services, and the Internet above all, will help bring prosperity to the most disadvantaged sectors of society.

\section{RESEARCH METHODOLOGY}

This study was conducted in order to assess the present status of Akshaya Telecentres in Kerala. The researcher utilized the descriptive method using both qualitative and quantitative approaches. Respondents were randomly selected from various districts in Kerala. The entrepreneurs of Akshaya Telecentres who have been chosen in this study were surveyed using a structured questionnaire. The results of the survey were then processed by computing each survey item

\subsection{APPROACHES OF THE STUDY}

The study employed both qualitative and quantitative approaches. This study employed the combined approach so as to overcome the limitations of both approaches. The aim of the survey is to obtain pertinent data to achieve the research objective. Representative samples were chosen using random sampling approach. The responses were gathered by using a selfadministered questionnaire.

\subsection{POPULATION}

All Akshaya Telecentre Entrepreneurs in Kerala constituted the population for the study, i.e. 2392 numbers of Akshaya Telecentre owners

\subsection{SAMPLE SIZE}

For a 95\% confidence level in the known population of 2392 Akshaya Telecentres the sample size of 331 was estimated by keeping the confidence interval as 5 . This was rounded off to 350 samples. This calculation uses the following formula for the sample size.

$$
n=\frac{S S}{1+\left(\frac{S S+1}{N}\right)}
$$

where,

$S S=$ initial sample size, which is calculated using the following formula,

$$
S S=\frac{Z^{2} P(1-P)}{C^{2}} .
$$

$Z^{2}$ is the critical value of the Normal distribution at $0.5 \alpha$, for a confidence level of $95 \%, \alpha$ is 0.05 and the critical value is $1.96, C$ is the margin of error ( 0.5 in this research), $p$ is the sample proportion i.e. percentage of population picking a choice, expressed as decimal ( 0.5 in this research), $N$ is the population 
size i.e. 2392 in this study. Finite Population Correction has been applied to the sample size formula. This sample size (350) was allocated to each district proportionate to their total population size.

\subsection{DATA COLLECTION TOOL}

A questionnaire was prepared with the objective of collecting all relevant information required for achieving the research objectives.

\subsection{SAMPLING PROCEDURE}

The respondents for the study were randomly selected from each district to fill the proportion thus formed. For randomly selecting samples, Random number generators were used. Since the population was known, the same was numbered and the samples were drawn accordingly.

\subsection{SECONDARY DATA}

The secondary data, reports, and information were collected from various libraries, and archives of Akshaya Telecentre Project office. The literature on previous studies were accessed at University libraries, Sodhganga (online repository of $\mathrm{Ph} . \mathrm{D}$ thesis) and online platform of research journals like Proquest, EBSCO, Emerald insight etc. were also source of data for the study.

\subsection{LIMITATIONS OF THE STUDY}

The study is based on primary data collected from entrepreneurs only. The survey would have considered $360^{\circ}$ analysis, had it collected data from Akshaya Telecentre users, and found out the effectiveness and efficiency of Akshaya Telecentre entrepreneurs in delivering their services. The present Researcher could not take up a survey on users due to the constraints of resources

\section{TELECENTRE MOVEMENTS}

Three-quarters of the Indian population lives in rural and remote areas and has little to no access to information. Due to the variation in landscape and climate throughout India, the needs of rural communities can vary greatly. Further, India has 22 official languages and more than 45 spoken languages across the country therefore, one of the major challenges in providing efficient services through community e-centres is the availability of appropriate content in local languages. Other concerns include connectivity, reliable power, appropriate user-friendly technology, training and above all, changing the mindset of people to adapt and absorb new technologies and business processes [9].

The Department of Information Technology has been working on a wider proliferation of ICT-enabled community e-centres with a focus on improving rural service delivery. A policy framework is being evolved which would outline and calibrate government interventions to establish a large number of such centres across the country within a specific time period. Records available for the last five years report that at least 200 initiatives in the field of citizen services, education, health, and e-governance related ICT kiosks community centres have been set up in rural India. These have been initiated by both government and non-government agencies.

The Department of Information Technology is the lead agency spearheading the Government's initiatives. The success of these initiatives has varied, but among these projects there have been some encouraging successes which are scalable and replicable. These include the following projects: Rural Access to Services through the Internet (RASI), e-Chaupal, Akshaya, TARAhaat, Community Information Centre (CIC), e-Seva, and Drishtee. Internet can empower rural India by providing access to education, health care and livelihood opportunities. Therefore, innovative technologies and applications need to be developed that cater specifically to rural areas [1]. It is evident now that information and communication technologies (ICT) will change the way people live, work, learn and entertain themselves. It will also change the way that governments operate worldwide. In India, the impact of rapid proliferation of ICT on economic, social and communication structures has been significantly visible for the last decade or so. However, a vast majority of the rural population has yet to benefit from this great technological revolution. The Government of India has appreciated the fact that without active interventions from the Government in the first place and from the other civil society organizations, this increasing impact of ICT would result in the creation of a host of divisions in the society [2].

Although any given kiosk is unlikely to provide all of these services, none are able to survive without offering at least a few of the following E-government, Education, Communication, Agriculture services, Entertainment, Community/religion services or professional services in India. The National Alliance for Mission 2007, representing a coalition of the concerned will facilitate and accelerate the spread of the rural knowledge centre movement and will function, like the Consultative Group on International Agricultural Research (CGIAR), without a legal structure. Under the National Virtual Academy three block level offices have been connected with the help of ISRO. Through this network, services such as e-education, e-medicine, online decision support, interactive farmers' advisory services, Telefishery, e-governance, and weather and water management services can be provided. This programme will cover both farming and fishing families, based on the motto: "Food, water, health, literacy and work for all and forever [26].

India where $72 \%$ of its one billion citizens live in more than half-a million villages, this would surely result in increasing disparity, alienation and social tension and further marginalization of a large number of its people in villages. On the other hand, ICT, if wisely deployed, with its inherent advantages, could very well be the most effective instrument to reduce the divide between "haves' and 'have not's" in this part of the world [23].

The telecommunication revolution in India is now primarily riding on mobile communications technology which is wireless at its major segments. Presently, every month, two million new mobile subscribers are added to the net, including rural India also. It may be mentioned here that out of over 600 districts in India, about 510 are classified as rural districts. However, Internet connections are at 400 per 10,000 and broadband connections two per 10,000, which are very far from the critical mass required for full exploitation of its advantages. Local "economic opportunity" is fast pulling the power of computing into communities, creating 
new types of work, increasing access to the capital and reducing the opportunity costs associated with various services and access to information.

The cost of computing capacity is dropping and the growing capacity of computing is being incorporated in a wide variety of form factors that are differentially accessible to Indian people with a wider variety of income and assets. Cellular networks are helping to overcome barriers of difficult terrain and distance, primarily for voice communications. Newer technologies like WiFi, corDECT, Wi-Max etc. are going to overcome additional challenges of terrain, infrastructure, capacity building, government procedures etc. With device convergence and advancement of multimedia applications, computing is now taking on forms that fit with the life styles and environment characteristics of Indian people living in less developed rural conditions [2].

Presently there is a nationwide awareness of growing economy in rural India. There are increased interactions between rural areas and cities and even between rural areas and other nations. Large Indian corporate business houses, multinational corporations and smaller, more targeted business entities, are increasingly and directly touching the lives of rural Indians with valued products and services [9]. Against this backdrop, some state governments in India, various civil society entities, NonGovernment Organizations and local entrepreneurs have started, independently, building up ICT-enabled CeCs. Although these are functioning with various nomenclature, they all rely on ICT, in combination with innovative and unique business models (including government-sponsored centres), to catalyze local economic development and bring various products and services to rural Indians. Some of these successful pilot initiatives have been rolled out in limited ways across the states. At this point of time, there are about 10,000 such community e-centres established under different initiatives, serving a limited population of villages across the country.

The Government of India has taken up the National eGovernance Action Plan (NEGAP) to proliferate e-governance in a faster way for delivering Government-to-Government $(\mathrm{G} 2 \mathrm{G})$ and Government-to-Citizen (G2C) services within a stipulated period. For this purpose, NEGAP has identified 22 Mission Mode Projects (MMP), which are to be implemented in a phased manner over the next three to four years by the various line Ministries and Departments concerned at the Central and State levels, as applicable, in addition to the various other e-governance initiatives being undertaken by the respective States and Central Ministries.

An Integrated Citizen Service Centre or Community e-Centre (CeC) has been identified as an element of the support infrastructure, one of the MMPs in the NEGAP, which would function as the delivery outlet for some of these e-governance initiatives. The Department of Information Technology (DIT) has been identified as the nodal department to implement this Mission Mode Project of Community e-Centre [9].

During the last decade ICT has experienced extraordinary growth, which has facilitated greater flow of resources, including monetary capital, physical goods, human resources, and most importantly, information. ICT helps people to communicate effectively, overcoming the limitations of time and space, empowers people by providing information and knowledge, provides income generating and learning opportunities, increases government transparency and efficiency, and enables people to express their concerns and to actively participate in decisionmaking processes. ICT penetration and application vary significantly across the region that makes the benefits of ICT not universal, leading to the creation of the digital divide between and within countries. Therefore, the challenges faced by various stakeholders and international organizations are to narrow the digital gap and create digital opportunities by providing people with equitable, affordable, quality and universal access to ICT. The community e-centre $(\mathrm{CeC})$ or Telecentre is one way of providing access to ICT to rural communities [16].

A Telecentre is a community centre that offers shared access to ICTs for the purpose of community development and poverty reduction. Telecentres are being promoted as an answer to the problems of the digital divide, whereby large sections of society do not enjoy access to ICTs and are therefore at risk of being excluded from the socio-economic benefits that such access brings. Uncertainty about how to finance Telecentres is hindering their spread and slowing down the delivery of the benefits that they are capable of delivering to even the poorest sections of society [19]. Telecentres are owned and operated by a variety of institutions, including; Non-Governmental Organizations (NGOs), Community-Based Organizations (CBOs), private individuals and companies, aid agencies, universities and research institutions, and governments.

These institutions all share the goal of using ICTs to bring about socio-economic development. Telecentres are known by different terms such as, telecottages, community e-centres, multipurpose community Telecentres, multimedia community centres, village information shops, info-kiosks and community or village knowledge centres. Telecentres are distinguished from cyber cafés by their development focus, as cyber cafés, which can bring development benefits and serve to acculturate the public towards ICTs, but exist only for profit, with little concern as to how their technology is used. Additionally, Telecentres are increasingly operating in clusters and networks; co-operating with each other to leverage their resources. A model that allows for wide distribution of generic services but which at the same time is able to foster local variations, is a particularly effective arrangement [24].

\subsection{TELECENTRE APPROACH OF KERALA}

Administrative Reforms Committee (ARC) was constituted to recommend strategies to strengthen state administration. The 15 reports of the ARC (consolidated as ARC Report, 2002) recommended that government department's agencies should network their functions and provide integrated services to citizens. The reports strongly favoured flexible forms of organising, outsourcing and contractual relationships. On account of the weak fiscal situation in the late 1990s, the state government decided to take external financial help from the Asian Development Bank to the tune of US\$775 million. ADB insisted on the conditionality of governance reforms and were agreeable to consider the recommendations of ARC as the reforms agenda through Modernising in Government Programme (MGP), ADB promoted the agenda and pressurized the state to consider and confine its role to that of a facilitator in the economy [5]. 
Through the implementation of ARC recommendations and MGP, neo-liberal reforms took roots in Kerala. The key component of MGP was the deployment of ICT for improving efficiency and promoting the delivery of citizen services in an integrated manner. In 1998, the state announced its first ICT policy and set up a Department of Information Technology in the same year. The field level office of the department, Kerala state Information Technology Mission (KSITM) was established in the year 1999. The announcement of the IT policy, the state set up a few task forces to identify specific strategies and prepare roadmaps to ensure that the policy could be operationalised. One of the task forces was constituted to propose strategies for the implementation of ICT in government. The task force reviewed the then. As per a State Government order Go (Ms) 7/97/PandARD Dated, 26-5-1997, some members of ARC became consultants to MGP [13]. KSITM had created an interactive $\mathrm{CD}$ wherein people designated as below the poverty line (BPL) could see and decide on government through a project called Thanal, supported housing possibilities. The project, however, failed to serve the purpose due to the lack of wide spread ICT access. The penetration of ICT was highly limited though the state had good digital and social infrastructure. Connectivity was an urban phenomenon and Internet penetration in 2000 was estimated to be around 0.75 percent [13].

The task force recommended that the e-Governance activities in the state should shift the focus towards attempting projects that gave direct services to citizens. The recommendation also incorporated the notion of efficiency by prioritising e-governance in departments that were primarily involved in collecting government taxes. Thirty four departments' agencies were identified for introduction of e-governance in the first phase based on their degree of citizen interface and their degree of revenue collection. It was felt that such attempts would not satisfy the integrated services delivery strategy of the government.

KSITM developed a few projects in this regard. In partnership with State Library Council, KSITM conceived project Sevana as the mechanism for providing e-governance services in a decentralised manner through the strong and existing network of rural libraries in the state [29]. The project was initiated with the provision of Internet access. KSITM, on the difficulties of managing delivery mechanism within government, they attempts to provide integrated delivery of services through Keltron kiosks also did not work. The other people-oriented project that was conceived by KSITM in year 1999 was Friends. This learning profoundly influenced KSITM's decision to adopt an entrepreneurial model when it came to Akshaya project.

\subsection{GENESIS OF AKSHAYA PROJECT}

The constitution of democratic decentralised institutions in the state, in line with the 73rd and 74th constitutional amendments undertaken by Indian Parliament has a significant role in the specific context of this project. The state has democratically elected local self-governing institutions (LSGIs) at the district, block and village levels. Apart from them, the state also has 6 Corporations (urban local bodies) and 54 Municipalities (semi urban local bodies). There are 14 district level local bodies, 152 block level local bodies and 999 village level local bodies LSGs have some freedom to design and implement projects according to their local requirements using one third of the consolidated funds of the state [13].

The decentralised local governments played a major role in the Akshaya Telecentre project. KSITM found in the concept of Telecentres the possibility of aligning the interests of the state as well as district panchayath. This was based on the earlier experiences with trying to provide access discussed above as well as the research on a wide body of literature related to use of ICT for development. The team identified that a set of prerequisite conditions need to be in place for such a project to be successful. The identified conditions included ICT skill base of population, accessibility, connectivity and availability of relevant local content [13].

The project team proposed that the ICT scenario of the state required state intervention (for critical mass creation) considering the sub-optimal levels of demand (usage) and supply (content) markets. This thinking led to the idea that a critical mass of ICT access centres, critical mass of users (through the literacy programme) and critical mass of locally relevant content would serve as basis of activities for the project. The project was hence conceived with the following activities (a) access - setting up of multipurpose ICT centres Telecentres (b) skill - functional ICT literacy to at least one person in every family and (c) content and ICT services- creation of adequate and relevant local content, and ICT services and (d) connectivity - providing connectivity. The Telecentre project (titled Akshaya project by then) incorporating the above elements was approved by district panchayath in October 2002. Subsequently, on November 18, 2002, Dr. A.P.J. Abdul Kalam the then President of India officially launched the project for the whole of the state [13].

\section{DATA ANALYSIS}

The questions and responses were coded and entered in the computer using Microsoft Excel software. Required analyses were done with the aid of Statistical Package for Social Sciences Version 21. Percentage analysis and Friedman test were applied on the data to get the results for analysis. The procedures used for the analysis of the research questions of this study are described below. In order to obtain a deeper understanding of some of the entrepreneurial profile of the Akshaya centres work behaviour, psychological behaviour and core competence of the Akshaya entrepreneurs were examined. Organization form, capital resources, human resources and receipts and income of Telecentres were also analyzed in the study. The respondents of the present research has been broadly classified under two major heads namely (a) The entrepreneur (b) The entrepreneurial firm.

\subsection{THE ENTREPRENEUR}

This category classifies the entrepreneur or the promoter of the Akshaya Centre based on his personal profile as Demographic profile, psychological factors, work behavior and core competencies.

\subsubsection{Demographic Profile:}

The first sub section classifies the respondents (owner) of the centre based on the demographic profiles such as education, age, religion, marital status, family members etc. It can be observed from the above table that $55.40 \%$ of the respondents of the present 
study were males, and the rest were females, since the respondents were all owners of the centres it is worth- noting that there is almost an equal proportion of both the genders, which is a good sign.

Another important classification is based on the age of the respondents, it can be seen that the majority (51.40\%) belongs to the middle age (between 30 and 39), followed by those above 40 and there are only a very few in the age group of less than 30 .

The third subsection under demographic profile of respondents points to the spread of respondents based on religion, were in majority of the respondents were hindus $(57.10 \%)$ followed by Islam and Christians respectively. When it comes to marital status, it can be observed that most of the respondents are married $(87.70 \%)$, while the other two categories, as unmarried divorced are negligible, a pattern which is natural, given the spread of the respondents based on age.

Further the respondents are classified based on the Educational background, it can be noted that the majority $(71.10 \%)$ are Under Graduates, this pattern will go in tune to the fact that Kerala is a state popular for its high rate of literacy, $13.7 \%$ of the respondents have completed high school, while the rest the share of Post graduates and Plus two qualified entrepreneurs follow with $7 \%$ apiece.

Table.1. Demographic Profile of the Akshaya Entrepreneurs

\begin{tabular}{|c|c|c|c|c|c|c|}
\hline \multicolumn{4}{|c|}{ Gender } & Male & Female & Total \\
\hline \multicolumn{4}{|c|}{ Percent } & 55.40 & 44.60 & 100 \\
\hline Age & \multicolumn{3}{|c|}{ Below 30} & $30-39$ & $\begin{array}{l}40 \text { and } \\
\text { above }\end{array}$ & Total \\
\hline Percent & \multicolumn{3}{|c|}{14.00} & 51.40 & 34.60 & 100 \\
\hline Religion & \multicolumn{3}{|c|}{ Hindu } & Christian & Muslim & Total \\
\hline Percent & \multicolumn{3}{|c|}{57.10} & 16.00 & 26.90 & 100 \\
\hline $\begin{array}{l}\text { Marital } \\
\text { Status }\end{array}$ & \multicolumn{3}{|c|}{ Unmarried } & Married & Divorced & Total \\
\hline Percent & \multicolumn{3}{|c|}{8.30} & 87.70 & 4.00 & 100 \\
\hline Education & \multicolumn{2}{|c|}{$\mathrm{H} \mathrm{S}$} & $\begin{array}{l}\text { Plus } \\
\text { Two }\end{array}$ & U G & P G & Total \\
\hline Percent & \multicolumn{2}{|c|}{13.7} & 7.4 & 71.1 & 7.7 & 100 \\
\hline $\begin{array}{c}\text { Family } \\
\text { Members }\end{array}$ & Two & Three & Four & Five & $\begin{array}{c}\text { Six and } \\
\text { above }\end{array}$ & Total \\
\hline Percent & 6 & 17.4 & 32. & 34.6 & 10.00 & 100 \\
\hline \multicolumn{2}{|c|}{ Earning Members } & One & \multicolumn{2}{|c|}{ Two } & Three & Total \\
\hline \multicolumn{2}{|c|}{ Percent } & 37.7 & \multicolumn{2}{|c|}{57.4} & 4.9 & 100 \\
\hline $\begin{array}{l}\text { Major } \\
\text { Income }\end{array}$ & $\begin{array}{c}\text { Akshay } \\
\mathrm{a}\end{array}$ & \begin{tabular}{|c} 
Other \\
Busine \\
ss
\end{tabular} & $\begin{array}{c}\text { Agricu- } \\
\text { lture }\end{array}$ & $\begin{array}{l}\text { Other } \\
\text { Job }\end{array}$ & $\begin{array}{l}\text { Passive } \\
\text { Income }\end{array}$ & Total \\
\hline Percent & 67. & 2.0 & 13. & 4.0 & 3.1 & 100 \\
\hline
\end{tabular}

The next category classifies the respondents based on the family background, most of the respondents belong to family with $4(32 \%)$ to $5(34.60 \%)$ members, again a pattern which can be similar to the general pattern of family size in Kerala.17.40\% of the respondents have family size of three members, followed by above 10 and 2 members (10\% and $6 \%$ respectively).
Another important categorisation when it comes to entrepreneurship is the number of earning members in the family, among the respondents of the current study it can be noted that the majority of respondents $(57.40 \%)$ come from a family which has two earning members, which is a growing trend among families in India currently, followed by $37.70 \%$ which is single earner families and the rest $4.90 \%$ with 3 earning members or more. To analyse the dependence of respondents on the ICT centres, the researcher had quizzed on the major source of income, among the respondents $67.7 \%$ had depended on Akshaya center as their major source of income, a spread which makes the sustainability of the Akshaya project a necessity, while $13.1 \%$ depended on other businesses and 12\% Depended on agriculture, only a negligible share of respondents are depended on other jobs or other sources of income.

\subsubsection{Work Behaviour:}

The second part of entrepreneur characteristic classifies the respondent based on their work behaviour by considering the role played and time spend by the entrepreneur at the Telecentre.

While the larger chunk are involved either in managing the store $(38.0 \%)$ or in the operation of the store $(33.9 \%)$ and $27.80 \%$ are controlling the finance. Regarding hours spend in the centre per week, half of the respondents are spending in between 40 to 59 hours a week, which in a typical six day work week will make it 7 to 10 hours spend in the centre during a day, while among the rest about $25 \%$ of respondents spend more than 60 and above hours, this trend comes in continuation to the former classification, as most of the members are involved in the operations of the centre, it is only natural to be spending longer time, while only $16.6 \%$ of the respondents spend below 20 hours and $8.6 \%$ spend between $20-39$ hours in the centre.

Table.2. Work Behaviour of the Akshaya Entrepreneurs

\begin{tabular}{|c|c|c|c|c|c|}
\hline $\begin{array}{c}\text { Major } \\
\text { Role }\end{array}$ & Operator & \multicolumn{2}{|c|}{ Manager } & $\begin{array}{c}\text { Financial } \\
\text { Controller }\end{array}$ & Total \\
\hline Percent & 33.90 & \multicolumn{2}{|c|}{38.30} & 27.80 & 100 \\
\hline $\begin{array}{c}\text { Hours } \\
\text { Spend in } \\
\text { Centre }\end{array}$ & Below20 & $20-39$ & $40-59$ & $\begin{array}{c}60 \text { and } \\
\text { Above }\end{array}$ & Total \\
\hline Percent & 16.6 & 8.6 & 50.3 & 24.6 & 100 \\
\hline
\end{tabular}

\subsubsection{Psychological Motives:}

The third sub category classifies based on the psychological motivations of the respondents, it tries to identify their perception regarding the stage of psychological hierarchy they belong to. This dimension was measured using a few statements which quizzed on their drives behind commencing the business. The respondents were asked to rate these factors in a 5 point scale. Further, these ratings were converted to rank Friedman test method was used to rank the psychological motives.

It could be identified from the table that the biggest driver is learning and personal growth, closely in pursuit is social status, followed by Independence, personal achievement, flexibility in life, satisfying work relationships, testing own ideas, securing future, wealth creation, economic necessity, in that order. 
Table.3. Ranking of Psychological Motives

\begin{tabular}{|c|c|c|c|}
\hline Item & $\begin{array}{l}\text { Mean } \\
\text { Rank }\end{array}$ & \multirow{7}{*}{\multicolumn{2}{|c|}{ Test Statistics a }} \\
\hline $\begin{array}{l}\text { Learning and Personal } \\
\text { Growth }\end{array}$ & 6.68 & & \\
\hline Social Status & 6.21 & & \\
\hline Independence & 6.01 & & \\
\hline $\begin{array}{l}\text { Satisfying Work } \\
\text { Relationship }\end{array}$ & 5.88 & & \\
\hline Personal Achievement & 5.81 & & \\
\hline Test my Own Ideas & 5.71 & & \\
\hline Flexibility in Life & 5.69 & \multicolumn{2}{|c|}{ N 350} \\
\hline Securing Future & 4.84 & Chi-Square & 366.365 \\
\hline Wealth Creation & 4.23 & Df & 9 \\
\hline Economic Necessity & 3.94 & Asymp. Sig. & .000 \\
\hline Source: Data Analysis & & a. Friedman Tes & \\
\hline
\end{tabular}

\subsubsection{Core Competencies:}

The fourth dimension of the entrepreneurship profiling looks at the competencies of the entrepreneurs The competencies for running the centre has been identified based on broadly two dimensions as Training received and experience (in both managing and operating the centres).

It can be observed from the table below that just above half of the respondents $(51.4 \%)$ have received training while the later doesn't have that exposure. While when it comes to experience in managing, $33.7 \%$ have 6 to 10 years of prior experience, while $24.3 \%$ said they have no prior experience in managing. $17.1 \%$ held an experience of 1 to 5 years, followed by those with 11 to 15 years and finally $8.9 \%$ with more than 15 years of experience.

Table.4. Entrepreneurial Competencies

\begin{tabular}{|c|c|c|c|c|c|c|}
\hline \multicolumn{3}{|c|}{ Entrepreneurship Training } & Yes & No & Total \\
\hline \multicolumn{3}{|c|}{ Percent } & 51.40 & 48.6 & 100 \\
\hline $\begin{array}{c}\text { Managerial } \\
\text { Exp (Years) }\end{array}$ & Nil & 1 to 5 & 6 to 10 & 11 to 15 & above 15 & Total \\
\hline Percent & 24.3 & 17.1 & 33.7 & 16.0 & 8.90 & 100 \\
\hline $\begin{array}{c}\text { Operator } \\
\text { Exp (Years) }\end{array}$ & Nil & $1-5$ & $6-10$ & $11-15$ & above 15 & Total \\
\hline Percent & 44.3 & 17.40 & 26.6 & 5.70 & 6.0 & 100 \\
\hline
\end{tabular}

In the case of experience $44.3 \%$ of the total reported that they had no prior experience as operator, $26.6 \%$ of the respondents reported an experience of 6 to 10 years, followed by people with 1 to 5 years of experience $(17.4 \%)$ and people with 11 to 15 years and above 15 years of experience in operations being the least of $5.7 \%$ and $6 \%$ respectively.

\subsection{THE ENTREPRENEURIAL FIRM: AKSHAYA TELECENTRE}

Akshaya Telecentres are profiled by the researcher on the basis of their organisation form, capital resources, human resources and sources of revenue.

\subsubsection{Organisation Form:}

The researcher classified the organisation form of the Telecentres by depicting their type of business, year of establishment, transfer of ownership and the prologue of entrepreneurship.

It can be observed from the table 5 that most (95.1\%) of the Akshaya Telecentres are run as soleproprietorship and while the rest hold only negligible share. When it comes to year of establishment, Majority (40.3\%) of the centres are established in between 2006 - 2009 followed by 2010 - 2013 (29.4\%) and the period $2002-2005(27.1 \%)$.

Table.5. Organization Form

\begin{tabular}{|c|c|c|c|c|c|}
\hline $\begin{array}{c}\text { Business } \\
\text { Type }\end{array}$ & $\begin{array}{c}\text { Sole } \\
\text { Proprietor- } \\
\text { ship }\end{array}$ & $\begin{array}{c}\text { Family } \\
\text { Business }\end{array}$ & $\begin{array}{l}\text { Partner- } \\
\text { ship }\end{array}$ & Trust & Total \\
\hline Percent & 95.1 & 2.6 & 1.4 & 0.9 & 100 \\
\hline $\begin{array}{c}\text { Year of } \\
\text { Establishment }\end{array}$ & $2002-2005$ & $\begin{array}{l}2006- \\
2009\end{array}$ & $\begin{array}{l}2010- \\
2013\end{array}$ & $\begin{array}{l}\text { After } \\
2013\end{array}$ & Total \\
\hline Percent & 27.1 & 40.3 & 29.4 & 3.1 & 100 \\
\hline \multicolumn{3}{|c|}{ Self- Promoted } & Yes & No & Total \\
\hline \multicolumn{3}{|c|}{ Percent } & 76.3 & 23.7 & 100 \\
\hline \multicolumn{3}{|c|}{ First Business } & Yes & No & Total \\
\hline \multicolumn{3}{|c|}{ Percent } & 66.9 & 33.1 & 100 \\
\hline
\end{tabular}

Source: Data Analysis

In the case of prologue of entrepreneurship, sixty six percentages of the Telecentres were the first entrepreneurial venture of the owners, while $33 \%$ of the owners have moved into this after beginning in other businesses.

\subsubsection{Capital Resources:}

The second categorisation of the Telecentres is based on the capital resources used for the centre. Here the researcher considered sources and amount of capital contributed for the Akshaya centre.

Majority of the Telecentres used bank loan as the primary source of capital $(49.4 \%)$ followed by personal assets $(43.7 \%)$ and outside investor $(6.9 \%)$. In case of invested capital it can be observed that, $48 \%$ of the Akshaya Telecentres contributed within the range of rupees three lakh to rupees five lakh followed by those who have invested in between Rs. 100000 to Rs. 300000 $(30.3 \%)$.

Table.6. Capital Resources

\begin{tabular}{|c|c|c|c|c|c|}
\hline $\begin{array}{c}\text { Source of } \\
\text { Capital }\end{array}$ & \multicolumn{2}{|c|}{ Personal Assets } & $\begin{array}{c}\text { Bank } \\
\text { Loan }\end{array}$ & $\begin{array}{c}\text { Outside } \\
\text { Investor }\end{array}$ & Total \\
\hline Percent & \multicolumn{2}{|c|}{43.70} & 49.40 & 6.90 & 100 \\
\hline Capital (Rs) & $\begin{array}{c}\text { less than 1 } \\
\text { lakh }\end{array}$ & $\begin{array}{c}1-2.9 \\
\text { lakh }\end{array}$ & $\begin{array}{c}3-4.9 \\
\text { lakh }\end{array}$ & $\begin{array}{c}\text { Above 5 } \\
\text { lakh }\end{array}$ & Total \\
\hline Percent & 4.90 & 30.30 & 48 & 16.90 & 100 \\
\hline
\end{tabular}

It can also be observed that there are $16.9 \%$ of the Telecentres uses above rupees five lakh as their capital while $4.9 \%$ Telecentres are collected less than rupees one lakh as their capital 


\subsubsection{Human Resources:}

Human resources of the Telecentres are considered as another basis for profiling the enterprises. Researcher considered the services rendered by manager, owner, employee and relatives and classified based on their level of engagement as full time or part time. $89 \%$ of the centres under the study were managed by a single manager, while the rest are negligible.

Almost all $(99.1 \%)$ of the enterprises are getting fulltime services of owners in the Telecentres. Majority of the Akshaya Telecentres are run with single employee $(45.1 \%)$ followed by $38.9 \%$ staffing two employees, It can also be observed from the table that almost all of them $(96.9 \%)$ are considering only fulltime employees for the firm.

Table.7. Human Resources

\begin{tabular}{|c|c|c|c|c|c|c|}
\hline \multicolumn{4}{|c|}{ Manager (Fulltime) } & Zero & One & Total \\
\hline \multicolumn{4}{|c|}{ Percent } & 10.9 & 89.1 & 100 \\
\hline \multicolumn{3}{|c|}{ Owner (Fulltime) } & Zero & One & Two & Total \\
\hline \multicolumn{3}{|c|}{ Percent } & 0.6 & 99.1 & 0.3 & 100 \\
\hline $\begin{array}{l}\text { Employee } \\
\text { (Fulltime) }\end{array}$ & Zero & One & Two & Three & $\begin{array}{c}\text { Four } \\
\text { and } \\
\text { Above }\end{array}$ & Total \\
\hline Percent & 2.0 & 45.1 & 39. & 9.4 & 4.6 & 100 \\
\hline \multicolumn{3}{|c|}{ Relatives (Fulltime) } & Zero & One & Two & Total \\
\hline \multicolumn{3}{|c|}{ Percent } & 79. & 15.1 & 5.7 & 100 \\
\hline \multicolumn{3}{|c|}{ Manager (Part-time) } & Zero & One & Two & Total \\
\hline \multicolumn{3}{|c|}{ Percent } & 96.0 & 3.4 & 0.6 & 100 \\
\hline \multicolumn{2}{|c|}{ Employee (Part-time) } & Zero & One & Two & Four & Total \\
\hline \multicolumn{2}{|l|}{ Percent } & 96.9 & 2.3 & 0.6 & 0.3 & 100 \\
\hline \multicolumn{2}{|c|}{ Relatives (Part-time) } & \multicolumn{2}{|c|}{ Zero } & One & Two & Total \\
\hline \multicolumn{2}{|l|}{ Percent } & \multicolumn{2}{|c|}{96.3} & 3.4 & 0.3 & 100 \\
\hline
\end{tabular}

$15 \%$ of the centres reported that a relative is serving as their fulltime staff, followed by the $5.7 \%$ who had two relatives, while the majority $(79.1 \%)$ of the centre owners are not receiving any fulltime services from their relatives

\subsubsection{Sources of Revenue:}

The next dimension in classifying the centre was on basis of sources of revenue of the enterprise. The researcher considered financial support from the donor \& income received from centre.

Table.8. Sources of Revenue

\begin{tabular}{|c|c|c|c|c|c|c|}
\hline \multicolumn{4}{|c|}{ Red Tapes } & Yes & No & Total \\
\hline \multicolumn{4}{|c|}{ Percent } & 68 & 32 & 100 \\
\hline \multicolumn{3}{|c|}{ Income on weekdays } & $\begin{array}{c}\text { below } \\
1000\end{array}$ & $\begin{array}{l}1001- \\
5000\end{array}$ & $\begin{array}{c}10001- \\
15000\end{array}$ & Total \\
\hline \multicolumn{3}{|c|}{ Percent } & 85.4 & 8.6 & 6.0 & 100 \\
\hline $\begin{array}{c}\text { Income } \\
\text { on } \\
\text { weekends }\end{array}$ & $\begin{array}{c}\text { below } \\
1000\end{array}$ & $\begin{array}{c}1001- \\
5000\end{array}$ & $\begin{array}{l}5001- \\
10,000\end{array}$ & $\begin{array}{c}10,001- \\
15000\end{array}$ & $\begin{array}{c}\text { Above } \\
15000\end{array}$ & Total \\
\hline Percent & 46.6 & 42.6 & 2.9 & 0.6 & 7.4 & 100 \\
\hline
\end{tabular}

Source: Survey Data
From the above table it can be observed that majority $(68 \%)$ of the Akshaya Telecentres are facing difficulty in getting financial support, while (32\%) of the centres are not facing any difficulty in getting financial support. Eighty five percent of the Telecentres have received average income of below rupees one thousand on weekdays and a small percentage of entrepreneurs have received rupees one thousand to rupees five thousand $(8.6 \%)$ and above rupees five thousand $(6.0 \%)$.

Average income received on weekends shows a pattern, as it can be observed that more revenue is generated during weekends, compared to weekdays. The following observations have been made based on revenue flow on weekends and weekdays.

It can be noted that the income that centre receives during weekdays in majority of the cases $(85.4 \%)$ is less than Rs. 1000.

While it can be observed that daily revenues of above Rs. 1000 is reported rarely in weekdays.

It can be observed that during weekends also the larger majority (46.6\%) are earning up to only Rs. 1000.

While it is worth noting that $42.2 \%$ of the respondents have reported a revenue between Rs. 1001 and Rs. 5000 during weekends.

It is significant to note that, though only a small share, there are a few respondents $(7.4 \%)$ who earns revenues of above Rs. 20000 during weekends.

\section{FINDINGS}

The researcher has analysed the perception about the policy sustainability of the Akshaya Telecentres on the basis of demographics of the Akshaya entrepreneurs and the arrangements of Akshaya enterprises. Here the researcher has adopted from the method used to classify Entrepreneurs and Entrepreneurship in Africa (Kiggundu, 2002).

\subsubsection{Demographic Profile of Entrepreneurs:}

There are an equal proportion of both male and female entrepreneurs among the Akshaya Telecentres. It can be seen that the majority among them belongs to the age group between 30 and 40 ), followed by those above 40 and there are only a very few in the age group of less than 30. Demographic profile of respondents also points to the spread of respondents based on religion, which follows the structure of population in Kerala, were in majority of the respondents were Hindus followed by Islam and Christians respectively. When it comes to marital status, it can be observed that most of the respondents are married while the other two categories, as unmarried divorced are negligible, a pattern which is natural, given the spread of the respondents based on age. Further the respondents are classified based on the Educational background, it can be noted that the majority are Under Graduates; this pattern will go in tune to the fact that Kerala is a state popular for its high rate of literacy.

To analyse the dependence of respondents on the ICT centres, the researcher had quizzed on the major source of income, among the respondents majority had depended on Akshaya centre as their major source of income, a spread which makes the sustainability of the Akshaya project a necessity. 


\subsubsection{Work Behaviour of Entrepreneurs:}

The larger chunk is involved either in managing the centre, or in the operation of the store. A smaller portion is in controlling the finance of Akshaya Telecentres. Half of the respondents are spending in between 40 to 59 hours a week, which in a typical six day work week will make it 7 to 10 hours spend in the centre during a day, while among the rest about $25 \%$ of respondents spend more than 60 and above hours, this trend comes in continuation to the former classification, as most of the members are involved in managing or operations of the centre, it is only natural to be spending longer time.

\subsubsection{Psychological Motives of Entrepreneurs:}

This drives behind commencing the business was measured using the stage of psychological hierarchy they belong to. The biggest driver is learning and personal growth, closely in pursuit is social status, followed by Independence, personal achievement, flexibility in life, satisfying work relationships, testing own ideas, securing future, wealth creation, economic necessity, in that order.

\subsubsection{Core Competencies of Entrepreneurs:}

It can be observed from the analysis that just above half of the respondents have received training while the later doesn't have that exposure. Majority of the entrepreneurs are having managerial experience from their past jobs. But only half of the entrepreneurs are having experience as an operator.

\subsubsection{Organisation form of Telecentres:}

Most of the Akshaya Telecentres are run as sole proprietorship and while the rest hold only negligible share. Majority of the centres are established in between 2006-2009 followed by 20102013 and the period 2002-2005. In the case of prologue of entrepreneurship, sixty six percentages of the Telecentres were the first entrepreneurial venture of the owners, while the remaining thirty three percentages of owners have moved into this after beginning in other businesses.

\subsubsection{Capital Resources of Telecentres:}

Majority of the Telecentres used bank loan as the primary source of capital followed by personal assets and outside investor. In case of invested capital it can be observed that, about half of the Akshaya Telecentres contributed within the range of rupees three lakh to rupees five lakh followed by those who have invested in between Rs. 100000 to Rs. 300000 .

It can also be observed that there are a few of the Telecentres uses above rupees five lakh as their capital while a negligible number of Telecentres are collected less than rupees one lakh as their capital.

\subsubsection{Human Resources of Telecentres:}

Most of the centres under the study were managed by a single manager. Almost all of the enterprises are getting fulltime services of their owners half of the Akshaya Telecentres are run with single employee followed by staffing two employees. It can also be observed that almost all of them are considering only fulltime employees for the firm. A nominal percentage of Telecentres are receiving any full time services from their relatives.

\subsubsection{Sources of Revenue for Telecentres:}

Income that centre generates during weekdays in most of the cases is less than 1000. During weekends also the larger majority are earning up to only Rs. 1000 . It is worth noting that $42.2 \%$ of the respondents have reported revenue between Rs. 1001 and Rs. 5000 during weekends. But daily revenues of above Rs. 1000 are reported rarely in weekdays, while there are a few Telecentres, which earns revenues of above Rs. 20000 during weekends. Sixty eight percentages of the Telecentres are reported that there are red tapes in getting financial supports from the government, while the remaining Telecentres are not facing any difficulty in getting financial support from the government.

\section{CONCLUSION}

The relevant dimensions and subsequent content areas of entrepreneurial competencies vary by the nature of entrepreneurial task and context within which they are performed. The above discussion shows what is known about Telecentre entrepreneurs in terms of demographics, psychological, work behavior and competencies. In addition to the competencies of the entrepreneur, Telecentres require effective and dynamic organizational arrangements. Such arrangements are required for mobilizing, organizing, utilizing, developing and protecting resources. Entrepreneurial competencies of the Akshaya entrepreneurs and organizational arrangements of Akshaya Telecentres can play vital roles in Telecentre sustainability.

\section{REFERENCES}

[1] R. Alauddin, "Connecting People in Rural Communities through ICT the Grameen Telecom Experience", Proceedings of Asian Development Bank Regional Workshop, pp. 18-22, 2004.

[2] A. Anyal, "Building 20000 Community e-centres for Rural India. Economic and Social Commission", Proceedings of Asian Development Bank Regional Workshop, pp. 199-205, 2004.

[3] R. Chauhan, "National e-Governance Plan in India", Available http://i.unu.edu/media/unu.edu/publication/1377/report414. pdf.

[4] R.D. Colle and R. Roman, "Centers and Developing Nations", State of the Art, 1999.

[5] A. Cordella, "Government Policy, Public Value and IT Outsourcing: The Strategic Case of ASPIRE", The Journal of Strategic Information Systems, Vol. 21, No. 7, pp. 295307, 2012.

[6] J. Ernberg, "Telecentres and the Incubation of Public Policy", Journal of Development Communication, Vol. 12, No. 2, pp. 26-32, 2001.

[7] F.E. Etta and S. Parvyn-Wamahiu, "Introduction: Joining the Information Society", Communication Technologies for Development in Africa, 2003.

[8] B. Fillip and D. Foote, "Making the Connection: Scaling Telecentres for Development", Available at: https://www.fhi360.org/resource/making-connectionscaling-telecenters-development. 
[9] W. Gunawardena, "Models of Community E-Centres for the Poor Economic and Social Commission for Asia and the Pacific", Bali: Asian Development Bank Institute, pp. 72-81, 2014.

[10] R. Harris, "Telecentre 2.0. APDIP e-Note", Available at: http://www.unapcict.org/ecohub/resources/apdip-e-note14-telecentre-2.0-beyond-piloting/?searchterm=None.

[11] Heather Creech, "Evaluation of UNESCO's Community Multimedia Centres", Technical Report, International Institute for Sustainable Development, Available at: https://www.iisd.org/pdf/2006/cmc_evaluation_2006.pdf.

[12] C. Jauernig, "Review of Telecentre Sustainability Criteria for the Establishment of Sustainable Rural Business Resource Centres for SMEs in Developing Countries", Small and Medium Enterprises Branch, United Nations Industrial Development Organization, 2003.

[13] Kerala IT Mission, Available at: http://www.itmission.kerala.gov.in/akshaya.php

[14] E.K. Koh, "Bridging the Digital Divide-the Satellite Solution. Economic and Social Commission", Proceedings of Asian Development Bank Regional Workshop, pp. 11-18, 2004.

[15] J.D. Lee and H.D. Lee, "Economic Analysis of Community E-Centres for Rural Development", Proceedings of Asian Development Bank Regional Workshop, pp. 81-93, 2004.

[16] M.K. Mason, "Potential of Information and Communication Technologies (ICTs) for Developing Countries", Available at: http://www.moyak.com/papers/ngo-icts.html

[17] S. Molnar and L. Karvalics, "Two Models and Six Types of Telecentres: A Typological Experiment", Proceedings of $2^{\text {nd }}$ Biennial South African Conference on Spirituality and Healthcare, pp. 327-332, 2002.

[18] K. Yoshimura, "E-Learning Project Planning for Community E-Centres. Economic and Social Commission", Proceedings of Asian Development Bank Regional Workshop, pp. 29-33, 2004.

[19] Roger Harris, "Telecentre 2.0 beyond Piloting Telecentres", Technical Report, UNDP-Asia-Pacific Development Information Programme, pp. 1-42, 2007.
[20] S. Oestmann and A.C. Dymond, "Telecentres-Experiences, Lessons and Trends", Telecentres: Case Studies and Key Issues, Vol. 1, pp. 1-15, 2001.

[21] Wilfred Owen and Osei Darkwa, "Role of multipurpose community Telecentres in accelerating national development in Ghana", First Monday, Vol. 5, No. 1, pp. 631-632, 2000.

[22] F.J. Proenza, "Telecentre Sustainability: Myths and Opportunities", Available at: http://www.eforall.org/pdf/TelecenterSustainability.pdf.

[23] Economic and Social Commission for Asia and the Pacific Asian Development Bank Institute, "Building ECommunity Centres for Rural Development", Proceedings of Asian Development Bank Regional Workshop, pp. 6-11, 2004

[24] E.M. Rathgeber and E.O. Adera, "Gender and the Information Revolution in Africa", International Development Research Centre, 2000.

[25] Raul Roman, "Themes and Issues in Telecentre Sustainability", Institute for Development Policy and Management, University of Manchester, 2002.

[26] S. Senthilkumaran, "From a Small Beginning to a Mass Movement-National Alliance for Mission 2007: Every Village is a Knowledge Centre", Proceedings of Asian Development Bank Regional Workshop, pp. 66-72, 2014.

[27] B. Shadrach and S. Sharma, "Telecentre Sustainability", Proceedings of International Conference on Misnomers, Challenges, and Opportunities, Vol. 3, pp. 1-6, 2011.

[28] S.S. Shinde, "Stakeholder Partnerships for ICT in Rural Communities. Economic and Social Commission", Proceedings of Asian Development Bank Regional Workshop, pp. 51-58, 2004.

[29] David N. Townsend, G. Daniel Espitia, Sonia N. Jorge and Christopher B. Lee, "Telecentres and Telecommunications Development: Options and Strategies", David N. Townsend and Associates, pp. 1-25, 2001. 